\title{
PEMBELAJARAN RAGAM KELAS/ TINGKATAN (Multigrade Teaching) DI SEKOLAH DASAR (SD): Konsep dan Penerapannya
}

\section{Abstrak}

"Pembelajaran Ragam Kelas/Tingkatan (PRK/T)" tidak hanya terdapat di negara-negara yang sedang berkembang tetapi banyak juga di negara-negara maju. Pada umumnya, model "Pembelajaran Ragam Kelas/Tingkatan (PRK/T)" banyak diterapkan di Sekolah Dasar (SD). Artinya, banyak SD yang dikelola oleh beberapa orang guru dan bahkan oleh seorang guru (one-teacher school). Sedangkan lazimnya SD menerapkan sistem guru kelas (classroom teachers). Mengingat siklus atau masa belajar di SD berlangsung selama 6 (enam) tahun, maka ada 6 tingkatan (kelas) yang harus dilalui setiap siswa selama belajar di SD, yaitu dimulai dari kelas/tingkat 1 (grade 1) sampai dengan kelas/tingkat 6 (grade 6). Karena itu, setidak-tidaknya setiap SD dikelola oleh seorang Kepala Sekolah dan dibantu oleh 6 guru $(1+6)$. Namun tidak semua SD dapat menerapkan model $S D(1+6)$ terutama di negara-negara yang sedang berkembang dan miskin. "Pembelajaran ragam kelas/tingkatan" telah diterapkan di beberapa negara, seperti: Amerika Serikat, Australia, Cina, Finlandia, Indonesia, Inggris, Jepang, Jerman, dan Kanada. Dalam kaitan ini, konsep tentang "pembelajaran ragam kelas/ tingkatan" (multigrade teaching) dan berbagai pemikiran/ permasalahan yang terkait akan dibahas di dalam tulisan ini sebagai kontribusi terhadap penyelenggaraan SD model "pembelajaran ragam kelas/tingkatan".

*) Drs. Sudirman Siahaan, M.Pd., adalah peneliti bidang pendidikan pada Pusat Teknologi Komunikasi dan Informasi Pendidikan (PUSTEKKOM)-Departemen Pendidikan Nasional. 
Kata-kata kunci: Pembelajaran ragam kelas/tingkatan (PRK/ $\mathrm{T})$, pembelajaran yang ditunjang media (instruction-supported media), sekolah dasar kecil (small primary school), dan kelas ragam usia (multiage classrooms).

\section{PENDAHULUAN}

"Pembelajaran Ragam Kelas/Tingkatan (PRK/T)" tidak hanya terdapat di negara-negara yang sedang berkembang tetapi banyak juga diterapkan di negara-negara maju. Pada umumnya, Sekolah Dasar (SD) menerapkan sistem guru kelas (classroom teachers). Mengingat masa belajar di SD berlangsung selama 6 (enam) tahun, maka ada 6 tingkatan (kelas) di SD, yaitu dimulai dari kelas/tingkat 1 (grade 1) sampai dengan kelas/tingkat 6 (grade 6). Dengan demikian, setidak-tidaknya setiap SD dikelola oleh seorang Kepala Sekolah dan dibantu oleh 6 orang guru $(1+6)$.

Di berbagai tempat di mana lingkungan kehidupan sosial masyarakatnya sangat kondusif terhadap perkembangan pendidikan, maka banyak dijumpai SD yang dikelola oleh lebih dari 7 (tujuh) orang. Beberapa di antara guru tambahan ini adalah guru bidang pelajaran tertentu, seperti: guru agama, guru pendidikan jasmani dan kesehatan, guru kesenian atau guru keterampilan. Kondisi yang sebaliknya juga banyak terjadi di mana satu SD dikelola oleh hanya 1 orang guru atau sebagian lagi dikelola oleh 1 sampai dengan 3 orang guru. Keadaan SD yang demikian ini cukup banyak juga jumlahnya. Di negara-negara yang sedang berkembang dan negara-negara miskin, cukup banyak jumlah SD yang dikelola oleh 1 orang guru atau oleh 1 sampai dengan 3 orang guru. Pada umumnya, SD dengan kondisi yang sedemikian ini lebih banyak ditemukan di daerah-daerah pedesaan (rural areas).

Sehubungan dengan permasalahan yang telah dikemukakan sebelumnya, ada berbagai pertanyaan yang menarik untuk 
diperbincangkan, yaitu antara lain: (a) Mengapa ada SD yang hanya dikelola oleh 1 orang guru atau SD yang dikelola oleh 1 sampai dengan 3 orang guru?; (b) Bagaimana konsep pembelajaran ragam kelas/tingkatan (multigrade teaching) dilaksanakan oleh guru yang jumlahnya terbatas untuk siswa yang terdiri atas 6 tingkatan/kelas?; (c) Di negara-negara mana saja diselenggarakan SD dengan model pembelajaran ragam kelas/tingkatan?; (d) Bagaimana kegiatan pembelajaran dilaksanakan di SD model pembelajaran ragam kelas/ tingkatan?; dan (e) Masalah-masalah apa saja yang dihadapi dalam melaksanakan kegiatan pembelajaran ragam kelas/tingkatan?

Berbagai pertanyaan tersebut di atas akan dicoba dibahas dan sekaligus juga akan diuraikan berbagai informasi lainnya yang berkaitan dengan pembelajaran ragam kelas/tingkatan (multigrade teaching). Selain itu, pengalaman berbagai negara dan Indonesia dalam menerapkan konsep "pembelajaran ragam kelas/tingkatan (PRK/T)" di Sekolah Dasar akan diketengahkan juga sebagai upaya untuk memperkaya khasanah/wawasan pengetahuan bersama. Terjemahan dari istilah "multigrade teaching" yang digunakan di dalam tulisan ini adalah "pembelajaran ragam kelas/tingkatan" karena di dalam proses belajar-mengajar yang dilaksanakan, para siswa dikondisikan untuk senantiasa aktif belajar dan belajar mandiri baik secara perseorangan maupun kelompok, tanpa harus sepenuhnya tergantung pada guru.

\section{KAJIAN LITERATUR}

\section{a. Konsep Pembelajaran Ragam Kelas/Tingkatan (Multigrade Teaching)}

Ada berbagai istilah yang berkembang yang berkaitan dengan konsep "Pembelajaran Ragam Kelas/Tingkatan (PRK/T)", yaitu: Kelas Beda Tingkatan (Split-grade Classrooms), Kelas Ragam Usia (Multiage Classrooms), Sekolah Tunggal Tingkatan (Mono or Single-grade School), dan Sekolah Dasar Kecil (Small Primary Schools). Berbagai istilah ini akan dibahas pada uraian berikutnya dengan harapan akan dapat memberikan 
pemahaman yang jelas mengenai konsep "Pembelajaran Ragam Kelas/Tingkatan (PRK/T)" di Sekolah Dasar.

Pada umumnya, SD yang sering kita jumpai di berbagai tempat, baik yang ada di perkotaan, di pinggiran kota maupun di daerah pedesaan, mempunyai seorang Kepala Sekolah dan dibantu oleh 6 orang guru kelas. Dalam kaitan ini, seorang guru mengajar dan bertanggungjawab atas sekelompok siswa yang berada pada satu kelas/tingkatan (mono or single-grade classrooms). Di berbagai kota, banyak SD yang selain dilengkapi dengan guru kelas, dilengkapi juga dengan beberapa guru mata pelajaran lainnya, seperti: guru pendidikan kesehatan dan olahraga, guru kesenian, guru agama, dan guru keterampilan.

Pada SD yang menerapkan satu orang guru untuk setiap kelas (guru kelas) dan setiap kelas hanya berisikan para siswa satu tingkatan, maka di antara para siswa sendiri terdapat usia yang bervariasi atau tidak sama (ragam usia). Biasanya, perbedaan usia antar siswa yang berada di dalam satu tingkatan/kelas ini tidaklah terlalu jauh, hanya berkisar antara 1 sampai 3 tahun karena: (1) pada umumnya rata-rata usia anak yang masuk ke SD adalah relatif sama yaitu sekitar 7 tahun dan di samping itu, (2) terbukanya peluang atau kemungkinan bagi para siswa tertentu untuk mengulang kelas atau yang biasanya disebut tinggal kelas (repetition).

Di kebanyakan negara, penyelenggaraan model "pembelajaran ragam kelas/tingkatan" adalah karena didorong oleh kepentingan/kebutuhan bukan karena diperhadapkan pada berbagai pilihan yang tersedia. Artinya, yang menjadi satusatunya jenis atau model pendidikan yang memungkinkan untuk dapat diakses oleh para siswa hanyalah "pembelajaran ragam kelas/ tingkatan". Para orangtua tidak mempunyai pilihan lain untuk menyekolahkan anaknya ke sekolah tertentu yang disenangi. Pilihan yang ada hanyalah SD yang menerapkan "pembelajaran ragam kelas/tingkatan". Model "pembelajaran 
ragam kelas/tingkatan" ini telah cukup lama diterapkan di berbagai negara termasuk di Indonesia namun tidak banyak dipublikasikan oleh media massa. "Pembelajaran ragam kelas/ tingkatan" diartikan sebagai kegiatan pembelajaran sekelompok siswa dengan latar belakang usia, tingkatan/kelas dan kemampuan yang berbeda yang diajar oleh seorang guru pada saat yang bersamaan (http://www.id21.org/society/ 4aDF7.html).

Ada beberapa model atau pola pembelajaran yang dapat dikembangkan dalam "pembelajaran ragam kelas/tingkatan" tergantung pada situasi dan kondisi masing-masing daerah. Setidak-tidaknya, Oos M. Anwas mengajukan 5 model/pola pembelajaran ragam kelas/tingkatan sebagai bahan pemikiran, yaitu: (1) seorang guru menghadapi siswa yang berada pada dua ruangan untuk dua tingkatan kelas yang berbeda, (2) seorang guru menghadapi siswa dalam tiga tingkatan kelas yang berbeda dalam dua ruangan kelas, (3) seorang guru menghadapi dua tingkatan kelas yang berbeda dalam satu ruangan, (4) seorang guru menghadapi tiga tingkatan kelas yang berbeda pada dua ruangan kelas, dan (5) seorang guru menghadapi tiga tingkatan kelas yang berbeda dalam satu ruangan kelas (Anwas, 2002).

Berdasarkan hasil kajian Miller terhadap penelitian kualitatif tentang "pembelajaran ragam kelas/tingkatan" dikemukakan bahwa para guru yang mengajar di sekolah-sekolah yang menerapkan pembelajaran ragam kelas/tingkatan menghabiskan waktu yang jauh lebih banyak (dibandingkan dengan guru yang hanya mengajar satu kelas/tingkatan). Karena, para guru ini harus mengorganisasikan dan merencanakan kegiatan pembelajaran yang akan disajikan kepada siswa yang tergabung ke dalam 2 atau 3 tingkatan/kelas pada waktu yang bersamaan (Miller, 1991).

Menurut Takako Suzuki (Suzuki, 2004), penyelenggaraan "pembelajaran ragam kelas/tingkatan"sangat banyak jumlahnya 
di Jepang, terutama dapat dijumpai pada sekolah-sekolah dasar kecil yang berlokasi di daerah-daerah yang sedikit jumlah penduduknya. Sekalipun jumlahnya cukup banyak, namun di Jepang, ada sejenis pembatasan yang dilakukan oleh pemerintah, yaitu model "pembelajaran ragam kelas/tingkatan" ini hanya boleh menggabungkan 2 kelas/tingkatan yang berbeda ke dalam satu kelas atau ruangan untuk dikelola oleh seorang guru. Pada umumnya, para siswa dari 2 kelas/tingkatan yang digabungkan ini dibimbing/diajar oleh seorang guru dengan memperlakukan para siswanya sebagaimana halnya dalam pengajaran kelas tunggal (mono or single class).

Chris Berry mengemukakan 3 alasan penting mengapa model "pembelajaran ragam kelas/tingkatan" dibutuhkan di berbagai negara, dan tidak hanya di negara-negara yang sedang berkembang tetapi juga di negara-negara maju (Berry, 2004), yaitu:

1) "Pembelajaran Ragam Kelas/Tingkatan" pada Sekolah Dasar selalu dikaitkan dengan "Sekolah Dasar Kecil" yang terdapat di daerah-daerah terpencil dengan jumlah penduduk yang jarang. Pada model pembelajaran ini, kemungkinan saja, hanya ada seorang guru, atau 2 maupun 3 orang guru. Sekalipun dengan jumlah guru yang sangat terbatas ini, para guru tetap berkewajiban untuk menyelenggarakan siklus atau masa pendidikan SD yang lengkap atau standar. Jika ada 6 tingkatan di SD, maka setiap guru akan menerapkan pembelajaran ragam kelas dengan mengajar siswa gabungan yang berasal dari 2 atau lebih tingkatan dalam waktu yang bersamaan. Dengan hadirnya "model sekolah yang mendatangi masyarakat" ini, maka angka partisipasi pendidikan akan semakin meningkat karena dapat mendorong lebih banyak anak terutama anakanak wanita untuk masuk sekolah.

2) “Pembelajaran Ragam Kelas/Tingkatan" merupakan model pembelajaran yang biasa ditemukan di sekolah-sekolah 
dasar di wilayah perkotaan yang luas di mana peluang/ kemungkinan tidak hadirnya guru secara teratur untuk mengajar di dalam kelas sangat tinggi. Sebagai upaya untuk mengatasi ketidakhadiran guru di dalam kelas ini, maka setiap guru yang ada ditugaskan untuk senantiasa dapat menggantikan guru lainnya yang berhalangan hadir. Karena itu, setiap guru telah dikondisikan untuk dapat menerapkan pembelajaran ragam kelas/tingkatan.

3) "Pembelajaran Ragam Kelas/Tingkatan" cenderung dipandang sebagai suatu respons terhadap permasalahan pendidikan yang sudah jelas/konkrit. Misalnya, di negaranegara maju, model pembelajaran ragam kelas/tingkatan ini dikaitkan dengan perspektif ragam usia. Proponents terhadap pengelompokkan peserta didik berdasarkan keragaman usia mengemukakan bahwa ada alasan-alasan pedagogis untuk menempatkan peserta didik yang berragam usia di satu kelas, yaitu dapat menstimulasikan perkembangan sosial anak-anak dan mendorong kerjasama kelas yang lebih besar.

Salah satu pendekatan dalam pembelajaran ragam kelas/ tingkatan dan yang sekaligus juga merupakan karakteristik utama adalah adanya pemisahan atau segregasi. Guru membuat pemisahan yang jelas antara setiap tingkatan, setiap mata pelajaran, setiap kelompok anak yang berada di dalam kelas. Anak-anak yang termasuk ke dalam satu tingkatan diorganisasikan untuk berada dalam satu kelompok tersendiri. Sebagai contoh: anak-anak dari tingkatan/kelas 1 dan 2 duduk bersama membentuk satu kelompok. Demikian juga dengan anak-anak kelas 3 dan 4 . Kemudian, guru akan mencoba menjelaskan satu mata pelajaran kepada masing-masing kelompok secara bergantian. Artinya, akan ada pelajaran matematika untuk kelas 4 dan pelajaran matematika untuk kelas 5 dan demikian selanjutnya. 
Dari berbagai uraian yang telah dikemukakan dapatlah dikemukakan bahwa konsep "pembelajaran ragam kelas/ tingkatan" (multigrade teaching) mengandung beberapa kriteria, yaitu: (1) adanya penggabungan siswa yang berasal dari 2 atau lebih tingkatan, (2) seorang guru ditugaskan untuk membelajarkan para siswa gabungan yang terdiri dari beberapa tingkatan, (3) seorang guru melaksanakan tugas-tugas mengajarnya kepada para siswa gabungan secara serempak, dan (4) siswa secara individual maupun di dalam kelompok (tingkatan) tetap dikondisikan oleh guru untuk tetap aktif belajar sekalipun guru sedang memberikan bimbingan kepada siswa tingkatan tertentu.

Penggabungan para siswa yang hanya berasal dari 2 tingkatan dinilai masih relatif lebih mudah untuk dikelola oleh seorang guru. Kondisi pengelolaan kegiatan pembelajaran tentu akan jauh lebih sulit lagi apabila sekolah hanya dikelola oleh satu orang guru atau "Sekolah Satu Guru" (one-teacher schools) ataupun yang dikelola oleh 2 orang guru (two-teacher schools). Artinya, guru yang ada melaksanakan berbagai tugas, tidak hanya yang sifatnya akademik atau pembelajaran tetapi juga administratif. A. Little mengemukakan prosentase jumlah SD yang menerapkan model pembelajaran ragam kelas/tingkatan (terutama "Sekolah Satu Guru") di beberapa negara adalah: (1) Peru (40\%), (2) Northern Territory of Australia (40\%), (3) Swedia (35\%), (4) Zambia (26\%), dan (5) Perancis (22\%) (Little, 1995).

Selanjutnya, berdasarkan data International Bureau of Education UNESCO, prosentase jumlah guru yang bertugas pada sekolahsekolah yang menerapkan "Pembelajaran Ragam Kelas/ Tingkatan”, disajikan pada Tabel 1 berikut ini. 


\section{Tabel 1}

Negara dan Prosentase Jumlah Guru Mengajar pada Model Sekolah Dasar Ragam Kelas/Tingkatan (Sekolah Satu Guru)*)

\begin{tabular}{|c|c|c|}
\hline NO & NEGARA & $\begin{array}{c}\% \text { JUMLAH } \\
\text { GURU }\end{array}$ \\
\hline 1. & Spanyol & $47 \%$ \\
2. & Turki & $25 \%$ \\
3. & Luxemburg & $23 \%$ \\
4. & Negara-negara di & \\
& Amerika Selatan dan Tengah & $20-40 \%$ \\
6. & Perancis & $20 \%$ \\
7. & India & $16 \%$ \\
8. & Rusia & $15 \%$ \\
9. & Switzerland & $10 \%$ \\
10. & Skotlandia & $3,6 \%$ \\
11. & Inggris & $2,9 \%$ \\
\hline
\end{tabular}

*) Kondisi yang ada pada Tabel 1 adalah pada tahun 1950.

\section{b. Pengertian Berbagai Istilah yang Berkaitan dengan Multigrade Teaching}

Di dalam berbagai literatur, dapat dijumpai beberapa istilah yang berkaitan dengan "pembelajaran ragam kelas/tingkatan", yaitu: kelas beda tingkatan (split-grade classrooms), kelas ragam usia (multiage classrooms), dan sekolah dasar kecil (small primary schools). Berikut akan diuraikan pengertian mengenai masingmasing istilah ini.

1. Kelas Beda Tingkatan (Split-grade Classrooms)

Menurut Charlie Naylor, pembelajaran di "kelas beda tingkatan" (split-grade classrooms) merupakan bentuk yang paling banyak ditemukan di Sekolah Dasar (SD) di mana seorang guru hanya mengajar sekelompok siswa di satu kelas sepanjang waktu atau setidak-tidaknya hampir 
keseluruhan waktunya. Kelas yang tingkatannya terpisah biasanya terdiri atas siswa dari 2 tingkatan yang bertautan yang ditempatkan ke dalam satu kelas. Sebagai contoh, tingkat/kelas 2 dan 3 atau tingkat/kelas 4 dan 5 dijadikan satu kelompok, atau dalam bentuk kombinasi tertentu lainnya.

"Kelas Beda Tingkatan" merupakan salah satu tipe konfigurasi dari "Kelas Ragam Usia", yang kemungkinan saja dapat mencakup anak-anak dari suatu rentangan usia tertentu. Ada 2 alasan yang melatarbelakangi diselenggarakannya kelas ragam usia, yaitu: alasan yang didasarkan atas pertimbangan filosofis dan alasan yang berkaitan dengan pertimbangan administratif (Naylor, 2000).

Eleanore Hargreaves mengemukakan bahwa pembelajaran ragam kelas/tingkatan diartikan sebagai kegiatan pembelajaran yang dilakukan oleh seorang guru kepada sekelompok siswa yang terdiri atas beberapa kelompok kelas/tingkatan atau usia dalam waktu yang bersamaan. Di daerah-daerah pedesaan di negara-negara yang sedang berkembang, seorang guru diberi tugas untuk bertanggungjawab melakukan pembinaan 2 atau lebih kelompok siswa yang berbeda kelas/tingkatan. Penugasan guru yang demikian ini disebabkan karena sedikit atau terbatasnya jumlah siswa yang ada, termasuk juga guru dan sumber-sumber lainnya (Hargreaves, 2004).

Ada 4 (empat) keuntungan yang diperoleh dari penggabungan siswa dari usia yang berbeda, yaitu: (a) siswa yang lebih muda usianya dapat secara aktif memanfaatkan siswa yang lebih tua usianya untuk mengembangkan keterampilan dan mendapatkan pengetahuan; (b) interaksi para siswa yang berbeda usia memberikan peluang khusus kepada para siswa untuk berkreativitas dan mempraktekkan ketrampilan; (c) percampuran usia yang berragam 
memberikan peluang kepada anak-anak untuk menemukan teman lainnya yang sesuai dengan kemampuannya; dan (d) siswa yang berusia lebih tua secara aktif melimpahkan (assert) tanggungjawab kepada siswa yang lebih muda usianya dan mengembangkan secara terus-menerus pengertian yang tinggi mengenai tanggungjawab yang diemban (Feldman and Gray, 1999).

2. Kelas Ragam Usia (Multiage Classrooms)

Istilah "combination class", "gradeless", "multiage" pada umumnya digunakan sebagai suatu sinonim di bidang pendidikan. "Tanpa Tingkatan" atau "Ragam Tingkatan" mengacu pada suatu situasi di mana para siswa tidak dikelompokkan berdasarkan usia kronologisnya. Di dalam kelas-kelas yang demikian ini, para siswa yang berbeda usia dan kemampuan dikelompokkan ke dalam satu kelompok dan kemudian dikelompokkan lebih lanjut lagi ke dalam subkelompok berdasarkan tingkatan mereka bukannya berdasarkan usia fisik maupun kronologis.

3. Sekolah Tunggal Tingkatan (Mono or Single-grade School) Pengertian Sekolah Tunggal Tingkatan (Mono or Singlegrade School) adalah suatu sekolah di mana para siswa yang berada pada satu tingkatan diasumsikan kurang lebih memiliki kesamaan dalam usia dan kemampuan (Jain, 2004). Di negara-negara yang sedang berkembang, pembentukan tipe kelas yang menerapkan ragam tingkatan didasarkan pada alasan-alasan yang jelas. Alasan yang menjadikan faktor usia sebagai salah satu kriteria untuk masuk sekolah, khususnya di daerah-daerah pedesaan dan suku-suku terasing bervariasi. Selain itu, hal yang sudah bersifat umum adalah terbukanya kesempatan/peluang bagi para siswa untuk mengulang tingkat/kelas. Di India, mengulang kelas dan kembali masuk sekolah di sepanjang tahun merupakan fenomena yang bersifat umum di daerahdaerah pedesaan dan suku-suku terasing. Yang menjadi 
pertanyaan adalah mengapa berbagai sekolah bersedia menerapkan pendekatan yang demikian ini.

4. Sekolah Dasar Kecil (Small Primary Schools) Yang dimaksudkan dengan "Sekolah Dasar Kecil" adalah sekolah yang mempunyai jumlah guru lebih sedikit dari jumlah tingkatan yang ada; demikian juga dengan jumlah ruang kelas. Dapat saja sebuah SD Kecil hanya mempunyai 1 sampai dengan 3 ruangan kelas. Sebagai konsekuensinya, masing-masing kelas terdiri atas 2 tingkatan atau lebih. Sekolah Dasar Kecil ini biasanya ditemui di daerah-daerah pedesaan yang jarang penduduknya, baik di negara-negara yang sedang berkembang maupun di negara-negara maju. Kadangkadang Sekolah Dasar Kecil disebut juga sebagai sekolah yang menerapkan Pembelajaran Ragam Kelas/ Tingkatan (http://www.ioe.ac.uk/multigrade/definitions_of_terms.htm).

Salah satu tujuan dari Sekolah Dasar Kecil adalah merespons kebutuhan akan pendekatan kurikulum yang bersifat khusus pada kelas ragam kelas/tingkatan (multigrade classrooms). Yang menjadi intensi (intention) dalam hal ini adalah mengembangkan sebuah model kurikulum yang secara khusus ditujukan kepada para siswa yang belajar pada sekolah-sekolah yang menerapkan pembelajaran ragam tingkatan/kelas. Para guru yang mengajar di Sekolah Dasar Kecil mempunyai tanggungjawab untuk membina para siswa yang berada pada dua, tiga atau lebih tingkatan di dalam satu kelas sehingga pengelolaan kegiatan pembelajarannya menjadi suatu situasi yang unik dan sekaligus juga sangat menantang (Mulcahy, 1992). 


\section{b. Penerapan SD Model Pembelajaran Ragam Kelas/Tingkatan}

Pada sekolah ragam kelas/tingkatan, para guru mengajar 2 atau lebih tingkatan pada satu kelas. Pemerintah di beberapa negara mempromosikan sekolah-sekolah ragam kelas/tingkatan untuk para peserta didik yang tinggal di daerah-daerah pedesaan dan terpencil dengan jumlah penduduknya yang jarang dan kurang beruntung (disadvantaged). Dengan menghadirkan/ mendatangkan sekolah ke lingkungan anak-anak, maka Pemerintah mencoba mencari terobosan untuk (1) mengurangi kesenjangan pendidikan antara anak-anak di daerah perkotaan dan pedesaan serta (2) memberikan layanan pendidikan yang dapat diakses dengan mudah oleh anak-anak usia sekolah dalam rangka pelaksanaan Pendidikan Dasar Universal (Pridmore, 2002). Para guru yang akan ditempatkan pada sekolah-sekolah ragam kelas dibekali dengan pelatihan tentang cara-cara mengajarkan materi pelajaran yang berbeda kepada peserta didik yang berbeda namun berada pada satu kelas.

Berikut ini disajikan informasi singkat tentang Sekolah Dasar yang menerapkan "pembelajaran ragam kelas/tingkatan" yang terdapat di beberapa negara, yaitu sebagai berikut:

1) Jepang

Model Sekolah Dasar yang menerapkan "pembelajaran ragam tingkatan/kelas" di Jepang hanya diperkenankan untuk menggabungkan 2 tingkatan ke dalam satu kelas. Penggabungan 2 tingkatan ini dinilai masih relatif lebih mudah untuk dikelola oleh seorang guru. Kondisinya akan jauh lebih sulit lagi apabila Sekolah Dasar hanya dikelola oleh satu orang guru atau disebut dengan istilah "Sekolah Satu Guru" (one-teacher schools). Artinya, guru yang ada melaksanakan berbagai tugas, tidak hanya yang bersifat akademik atau pembelajaran tetapi juga yang sifatnya administratif. 
Sehubungan dengan kebijakan pemerintah Jepang yang hanya memperkenankan penggabungan 2 tingkatan ke dalam satu kelas, maka untuk kepentingan kegiatan pembelajaran, dikemukakan oleh Takako Suzuki bahwa pemerintah mengembangkan kurikulum khusus yang siklusnya 2 tahunan yang didasarkan pada kebijakan kurikulum nasional yang bersifat umum. Pengembangan kurikulum yang akan digunakan oleh guru yang mengajar di kelas-kelas ragam tingkatan ini disesuaikan juga dengan kondisi lokal.

Sekalipun telah dibekali dengan kurikulum khusus yang dikembangkan untuk kepentingan pembelajaran siswa pada kelas gabungan, namun dikemukakan oleh Takaku Suzuki bahwa para guru masih belum mengubah strategi kegiatan belajar-mengajarnya. Mereka masih menerapkan strategi belajar-mengajar untuk kelas yang hanya satu tingkat (Suzuki, 2004).

\section{2) Vietnam}

Di Vietnam, ukuran kelas pada SD ragam kelas/tingkatan hanya dapat menampung sekitar 20 anak. Seorang guru memberikan pelajaran yang berbeda pada waktu yang sama kepada peserta didik yang terdiri atas beberapa tingkatan yang berbeda. Sebagai contoh, ada satu kelas yang ditempati oleh 13 anak ( 3 wanita dan 10 pria) yang berasal dari 2 tingkatan/kelas dan di antara siswa ini hanya seorang anak yang berbeda tingkat/kelasnya. Pekerjaan ekstra yang diemban oleh para guru yang mengajar di sekolah ragam kelas/tingkatan mendapat tambahan gaji 50\% jika hanya menangani 2 tingkatan peserta didik dan tambahan $75 \%$ bagi para guru yang bertanggungjawab atas 3 atau lebih tingkatan peserta didik (Pridmore, 2004).

Banyak model pembelajaran ragam kelas/tingkatan di Vietnam. Seorang guru dapat saja bertanggungjawab untuk 
membina 2 sampai 5 kelas yang berbeda. Sejauh ini, sekolah-sekolah ragam kelas/tingkatan menyebar luas di daerah-daerah etnis minoritas. Tujuannya adalah untuk menyediakan pendidikan dasar kepada anak-anak yang kurang beruntung dengan cara menghadirkan sekolah mendekat kepada masyarakat di tempat anak-anak tinggal. Ada sekitar 2.162 SD yang menerapkan model pembelajaran ragam kelas/tingkatan, atau sekitar $1,8 \%$ dari jumlah keseluruhan SD dengan jumlah peserta didik sekitar 143.693 anak atau sekitar $38 \%$ dari jumlah populasi usia sekolah (Vu, 2004).

3) Peru

Menurut Patricia Ames, Peru memiliki sekitar 21.500 SD yang menerapkan model pembelajaran ragam kelas/ tingkatan di mana sekitar $96 \%$ di antaranya terdapat di daerah-daerah pedesaan. Jumlah guru yang ditugaskan pada sekolah-sekolah ragam kelas/tingkatan ini sekitar 41.000 orang atau mewakili sekitar $69 \%$ dari total jumlah guru. Sebagian besar sekolah (89\%) yang berada di pinggiran kota di Peru menerapkan model pembelajaran ragam kelas/tingkatan. Khusus mengenai "Sekolah Satu Guru”, menurut Tovar yang dikutip Patricia Ames mengemukakan bahwa di Peru terdapat sekitar 39\% dan tersebar di daerah-daerah pedesaan (Ames, 1989).

Karakteristik yang sangat penting untuk dikemukakan yang mempengaruhi situasi pendidikan di Peru menurut Patrcia Ames adalah (a) persebaran dan keterpencilan populasi (dispersion and isolation) di pedesaan; (b) kemiskinan desa (60\% penduduk yang tinggal di pedesaan adalah miskin dan $37 \%$ hidup pada suatu situasi yang sangat miskin; (c) ekonomi keluarga yang menuntut anak-anak anggota keluarga untuk bekerja; (d) perbedaan ragam budaya dan bahasa yang digunakan; dan (e) anak-anak di daerah pedesaan terlambat mengikuti pendidikan sekolah, tingkat 
mengulang kelas (repetition rate) yang tinggi dan seringnya terjadi gangguan tidak bersekolah. Kesemuanya ini semakin mewarnai variasi kelas-kelas ragam tingkatan (Ames, 2004).

\section{4) Indonesia}

Berdasarkan penelitian yang dilakukan Bray mengenai Sekolah Dasar Kecil (Small Primary Schools) di Kalimantan Tengah dikemukakan bahwa terdapat 460 SD yang dikelola oleh 1 sampai dengan 3 orang guru (Bray, 1987). Bahanbahan belajar yang digunakan oleh siswa dirancang secara khusus sehingga dapat dipelajari secara mandiri oleh siswa. Salah satu peluang yang terbuka dari ketersediaan bahanbahan belajar yang bersifat mandiri adalah memungkinkan para sukarelawan orang dewasa untuk dapat membantu para siswa melakukan kegiatan pembelajarannya. Konsep Sekolah Dasar Kecil di berbagai literatur diidentikkan dengan sekolah dasar yang menerapkan model pembelajaran ragam kelas/ tingkatan.

Sedangkan berdasarkan data yang disajikan oleh Badan Penelitian dan Pengembangan Departemen Pendidikan Nasional tahun 1990 terdapat sekitar 12.000 SD yang dikelola oleh guru yang harus mengajar lebih dari satu kelas (BALITBANG DEPDIKNAS, 1990). Beberapa faktor yang menyebabkan Sekolah Dasar menerapkan Pembelajaran ragam kelas/tingkatan antara lain adalah: (a) kekurangan guru, (b) keterbatasan ruang kelas yang tersedia di SD, dan (c) kondisi geografis yang sulit transportasi (PUSTEKKOM, 2002).

Untuk membantu para guru yang mengajar di SD dengan model "pembelajaran ragam kelas/tingkatan", maka Pusat Teknologi Komunikasi dan Informasi Pendidikan (PUSTEKKOM) telah melakukan perintisan pemanfaatan program audio interaktif di 10 SD yang tersebar di 10 propinsi pada tahun 2001 (PUSTEKKOM, 2002). Program audio 
interaktif ini mencakup mata pelajaran: (1) bahasa Indonesia, (2) IImu Pengetahuan Sosial (IPS), (3) IImu Pengetahuan Alam (IPA), (4) Matematika, dan (5) Pendidikan Pancasila dan Kewarganegaraan (PPKN). Program ini dapat dimanfaatkan siswa tanpa harus sepenuhnya dibimbing oleh guru. Sekalipun demikian, guru dituntut untuk memberikan penjelasan dan petunjuk kepada para siswa sebelum program dimanfaatkan.

\section{c. Keuntungan/Kesulitan Penerapan Pembelajaran di SD Model Pembelajaran Ragam Kelas/Tingkatan}

Apakah ada perbedaan kegiatan belajar antara sekolah yang menerapkan pembelajaran ragam kelas/tingkatan dengan model pembelajaran tunggal tingkatan? Menurut Veenman, sekalipun memang ada perbedaan namun perbedaannya sangatlah kecil. Ada 4 alasan yang dikemukakan oleh Veenman dalam menyimpulkan kecilnya perbedaan di bidang belajar antara kedua jenis model pembelajaran ini, yaitu:

1) Pengelompokkan sebenarnya tidak mempunyai kecenderungan mempengaruhi hasil kegiatan belajar, sebagaimana halnya dengan faktor-faktor organisatoris yang kurang begitu penting dibandingkan dengan praktekpraktek pembelajaran itu sendiri.

2) Penggunaan kriteria yang ketat dalam mensleksi siswa sehingga siswa yang terpilih adalah siswa yang dapat bekerja secara mandiri dan tidak memiliki banyak masalah tingkah laku.

3) Guru tidak mendapatkan pelatihan tambahan untuk melaksanakan pembelajaran ragam kelas/ tingkatan, dan kemungkinan saja mereka memilki sikap negatif terhadap pembelajaran ragam kelas/tingkatan sehingga berpengaruh terhadap keberhasilan pembelajaran ragam kelas/ tingkatan.

4) Mengingat pembelajaran ragam kelas/tingkatan menuntut waktu persiapan yang lebih banyak dan beban kerja guru yang lebih besar, maka para guru senantiasa berupaya 
meyakinkan para siswanya agar mampu mencapai tahap tertentu sebagaimana layaknya mereka mengarahkan siswanya pada model pembelajaran kelas tunggal (monograde teaching Veenman, 1996).

Selanjutnya, Paula Rogers mengemukakan beberapa keuntungan yang diperoleh siswa yang belajar pada sekolah yang menerapkan pembelajaran ragam kelas/tingkatan, yaitu: (1) bantuan dari sesama para siswa tidak saja hanya menguntungkan para siswa dari kelas yang lebih rendah tetapi juga para siswa dari di kelas yang lebih tinggi (kerjasama yang saling menguntungkan), (2) para siswa terkondisi untuk belajar secara independen karena para gurunya mendidik mereka untuk mengembangkan sikap independen dan efisien dalam belajar, (3) berkembangnya perasaan bangga di dalam diri para siswa karena mereka merasa lebih puas sekalipun sedikit mengalami friksi dalam kegiatan belajarnya dibandingkan para siswa sekelas yang hanya terdiri atas satu tingkatan (Rogers, 2002).

Chris Berry mengemukakan bahwa manfaat dampak "pembelajaran ragam kelas/tingkatan" dapat bersifat kognitif dan non-kognitif. Berbagai penelitian telah dilakukan mengenai manfaat atau dampak secara kognitif dari "pembelajaran ragam kelas/tingkatan". Penelitian yang telah dilakukan juga bervariasi tergantung pada berbagai kondisi yang berkembang (Berry, 2004). Beberapa penelitian mengungkapkan bahwa prestasi akademik para siswa SD dengan model "pembelajaran ragam kelas/tingkatan" tidak lebih baik dan juga tidak lebih buruk dibandingkan dengan prestasi akademik para siswa yang belajar di sekolah-sekolah biasa.

Sedangkan manfaat atau dampak "pembelajaran ragam kelas/ tingkatan" yang bersifat non-kognitif berdasarkan hasil penelitian yang dilakukan oleh UNESCO/APEID di 12 negara di kawasan Asia Pasifik sebagaimana yang dikutip oleh Angela Little adalah sebagai berikut: 
1) Peserta didik mempunyai kecenderungan untuk mengembangkan (a) kebiasaan bekerja secara independen dan (b) keterampilan belajar sendiri.

2) Kerjasama kelompok di antara para siswa yang berbeda usia dan tingkatan mempunyai kecenderungan berkembangnya etika, kepedulian dan tanggungjawab kelompok.

3) Peserta didik mengembangkan sikap positif tentang saling membantu satu sama lain.

4) Kegiatan-kegiatan belajar remedial dan pengayaan dapat ditata menjadi lebih produktif dibandingkan di kelas-kelas normal yang biasa (Little, 1995).

Berdasarkan hasil studi yang dilakukan pada sekolah-sekolah yang menerapkan pembelajaran ragam kelas/tingkatan, dikemukakan oleh para guru yang menjadi responden bahwa dibutuhkan beberapa sikap dan kualitas yang penting dimilki oleh para guru yang akan berperanserta dalam pelaksanaan pembelajaran ragam kelas/tingkatan, yaitu:

1) mempunyai dedikasi yang sangat tinggi, dan bersedia bekerja keras di luar jam-jam pelajaran sekolah;

2) mempunyai kepedulian yang tinggi demi kesejahteraan para siswanya;

3) mempunyai kesediaan untuk memberikan lebih banyak pilihan dan keleluasaan kepada para siswanya; dan

4) mempunyai kesediaan untuk melakukan eksperimen, mencoba berbagai gagasan baru, dan berani menghadapi berbagai resiko (Mulcahy, 1992).

Ada 4 bidang kritis tentang perubahan yang harus difokuskan agar upaya pengembangan sekolah-sekolah dasar yang menerapkan pembelajaran ragam kelas/tingkatan dapat berhasil, yaitu:

1) guru perlu mengembangkan seperangkat bekal teknikteknik mengajar dan praktek-praktek pengelolaan kelas;

2) guru membutuhkan berbagai masukan, baik yang bersifat 
materi maupun fisik, di antaranya yang sangat penting adalah bahan-bahan belajar terprogram (programmed learning materials) dan buku-buku teks (textbooks).

3) guru membutuhkan jaringan dukungan professional, baik yang bersifat lokal maupun yang lingkupnya lebih luas;

4) adanya kebijakan nasional yang berkaitan dengan model pembelajaran ragam kelas/tingkatan misalnya: pelatihan para guru dan administrator, pengadaan guru dan pengembangannya, dan pengembangan bahan belajar yang di rancang dan di kembangkanuntuk pembelajaran ragam kelas/tingkatan.

Agar para peserta didik dapat belajar secara efektif pada lingkungan Sekolah Dasar yang menerapkan pembelajaran ragam kelas/tingkatan, maka para guru perlu diorganisasikan secara baik, dilengkapi dengan berbagai sumber yang dibutuhkan, dan mendapatkan pelatihan yang baik di samping memiliki sikap yang positif terhadap model pembelajaran ragam kelas/tingkatan.

Beberapa kesulitan/masalah yang dihadapi oleh sekolahsekolah yang menerapkan "pembelajaran ragam kelas/ tingkatan" sebagaimana yang dikemukakan oleh Angela Little, antara lain adalah:

1) tidak adanya pelatihan yang diselenggarakan untuk mempersiapkan/membekali para guru yang ditugaskan mengajar di sekolah-sekolah dasar yang menerapkan "pembelajaran pada kelas ragam kelas/tingkatan". Dengan tidak adanya pelatihan pembekalan ini, maka para guru hanya mengandalkan pengalaman sebelumnya yang telah dimiliki untuk mengelola kegiatan pembelajaran di samping tentunya inisiatif atau prakarsa yang dikembangkan oleh para guru itu sendiri.

2) adanya sementara persepsi yang kurang pas mengenai sekolah-sekolah dasar yang menerapkan kegiatan 
pembelajaran ragam kelas/tingkatan. Persepsi yang kurang pas itu adalah bahwa "Sekolah Satu Guru" atau "Sekolah Dua Guru" yang berlokasi di daerah-daerah pedesaan dan yang terpencil sebagai sekolah-sekolah yang berprestise sangat rendah sehingga kebanyakan para guru yang ditempatkan adalah mereka yang berkualifikasi rendah atau yang tidak mempunyai kualifikasi mengajar.

3) keterbatasan berbagai sumber belajar untuk menunjang pelaksanaan kegiatan pembelajaran, terutama yang berupa buku-buku teks, bahan-bahan belajar lainnya, dan alat bantu mengajar. Kondisi guru yang kebanyakan berkualifikasi rendah, jumlah guru dan sumber belajar yang terbatas akan menjadi masalah yang serius bagi guru untuk membelajarkan para siswa (Little, 1995).

Berkaitan dengan keterbatasan sumber-sumber belajar, Pusat Teknologi Komunikasi dan Informasi Pendidikan (PUSTEKKOM) telah mengembangkan bahan-bahan belajar yang dapat digunakan untuk pembelajaran ragam kelas/tingkatan. Bahanbahan belajar ini berupa program audio interaktif yang pengembangannya didasarkan pada kurikulum SD yang berlaku dan mencakup mata pelajaran bahasa Indonesia, IImu Pengetahuan Sosial (IPS), IImu Pengetahuan Alam (IPA), Matematika, dan Pendidikan Pancasila dan Kewarganegaraan (PPKN). Sejauh ini, perintisan pemanfaatan program audio interaktif telah dilakukan di 10 SD yang tersebar di 10 propinsi. Tujuannya adalah untuk membantu para guru membelajarkan para siswanya.

\section{SIMPULAN DAN SARAN}

Pada umumnya, model SD dengan 1 orang guru atau antara 1 sampai dengan 3 orang guru, banyak ditemukan di daerah-daerah pedesaan (rural areas), baik di negara-negara yang sedang berkembang maupun di negara-negara maju. Ada beberapa alasan untuk menyelenggarakan model pembelajaran ragam kelas/ 
tingkatan, misalnya: keterbatasan jumlah anak-anak usia sekolah, keterbatasan jumlah guru yang ada, keterbatasan ruang kelas yang ada di sekolah, dan keadaan geografis yang sulit untuk mobilisasi penduduk. Beberapa di antara negara yang menerapkan "pembelajaran ragam kelas/tingkatan" adalah: Amerika Serikat, Australia, Cina, Finlandia, Indonesia, Inggris, Jepang, Jerman, Kanada, Nepal, Peru, Sri Lanka, Spanyol, Thailand, Turki, Vietnam, dan Yunani. Berkaitan dengan pembelajaran ragam kelas/tingkatan ini, ada beberapa istilah yang digunakan, misalnya: pembelajaran ragam usia (multiage teaching), kelas ragam usia (multiage classrooms), sekolah dasar kecil (small primary schools), dan kelas beda tingkatan (split-grade classrooms).

Pembelajaran ragam kelas/tingkatan diartikan sebagai kegiatan pembelajaran yang dilakukan oleh seorang guru kepada sekelompok siswa yang terdiri atas beberapa kelas/tingkatan atau usia dalam waktu yang bersamaan. Di daerah-daerah pedesaan di negara-negara yang sedang berkembang, pada umumnya seorang guru diberi tugas atau tanggungjawab untuk membina 2 atau lebih kelompok siswa yang berbeda kelas/tingkatan. Ada beberapa model penerapan pembelajaran ragam kelas/tingkatan, misalnya: (a) seorang guru menghadapi siswa yang berada pada dua ruangan untuk dua tingkatan kelas yang berbeda, (b) seorang guru menghadapi siswa dalam tiga tingkatan kelas yang berbeda dalam dua ruangan kelas, (c) seorang guru menghadapi dua tingkatan kelas yang berbeda dalam satu ruangan, dan (d) seorang guru menghadapi tiga tingkatan kelas yang berbeda dalam satu ruangan kelas.

Beberapa dasar pemikiran yang melatarbelakangi penyelenggaraan Sekolah Dasar dengan model pembelajaran ragam kelas/tingkatan di satu daerah/wilayah yaitu, antara lain dikarenakan sedikit atau terbatasnya: (a) jumlah siswa yang ada dan (b) jumlah guru yang terdapat di satu wilayah. Faktor lainnya adalah dikarenakan kondisi kesulitan geografis yang ada di satu daerah/wilayah sehingga membatasi mobilitas penduduk. Untuk dapat berhasil dalam 
mengelola Sekolah Dasar yang menerapkan pembelajaran ragam kelas/tingkatan, para guru hendaknya: (a) mempunyai dedikasi yang sangat tinggi dan bersedia bekerja keras setelah jam pelajaran sekolah berakhir, (b) mempunyai kepedulian yang tinggi demi kesejahteraan para siswanya, (c) memberikan lebih banyak pilihan dan keleluasaan kepada para siswanya dalam kegiatan belajar, dan (d) bersedia melakukan eksperimen, mencoba berbagai gagasan baru, dan berani menghadapi berbagai resiko.

Mengingat beban tugas dan tanggungjawab yang besar yang diemban oleh para guru yang mengajar di SD yang menerapkan kegiatan pembelajaran ragam kelas/tingkatan, maka dinilai sangat penting dan strategis untuk (a) membekali para guru yang akan ditugaskan mengajar di SD model pembelajaran ragam kelas/ tingkatan melalui pelatihan, (b) melengkapi SD yang menerapkan kegiatan pembelajaran ragam kelas/tingkatan dengan berbagai sumber belajar yang dapat dipelajari siswa secara mandiri, dan (c) memberikan insentif kepada para guru yang bertugas mengajar di SD yang menerapkan pembelajaran ragam kelas/tingkatan, misalnya saja berupa: tambahan honorarium dan percepatan kenaikan pangkat.

\section{KEPUSTAKAAN}

Ames, Patrcia. (2004). Multigrade Teaching in Japan, Peru, Sri Lanka, and Vietnam (4 views of multigrade). EID Group, Institute of Education, University of London. Sumber dari website: http:// www.ioe.ac.uk/multigrade/fulltext6JapPerViet.htm

Anwas, Oos M. (2002). "Pengembangan Model Pembelajaran Kelas Rangkap Berbantuan Media Audio di Sekolah Dasar" dalam Jurnal Pendidikan dan Kebudayaan, September 2002, Tahun Ke-8 No.: 038. Jakarta: Badan Penelitian dan Pengembangan Departemen Pendidikan Nasional.

Badan Penelitian dan Pengembangan Departemen Pendidikan Nasional. (1990). Statistik Persekolahan. Jakarta: Badan Penelitian dan Pengembangan Departemen Pendidikan Nasional. 
Berry, Chris. (2004). Multigrade Teaching: ADiscussion Document. Sumber dari website: http://www.ioe.ac.uk/multigrade/ fulltext8chrisberry.htm

Bray, M. (1987). Are Small Schools the Answer? Cost-Effective Strategies for Rural School Provision. London: Commonwealth Secretariat.

Feldman, J., Gray, P. (1999). "Some Educational Benefits of Freely Chosen Age Mixing Among Children and Adolescents." Phi Delta Kappan. Vol. 80, No. 7, 507-512.

Hargreaves, Eleanore. (2004). Multigrade Teaching: One Response to Jomtien. London: EID Group, Institute of Education, University of London. Sumber dari website: http://www.ioe.ac.uk/multigrade/ fulltext4hargreavesjontiem.htm.

Jain, Manju. (2004). Multiage Classroom at the Primary Stage: Some Initiatives. New Delhi-India: Department of Elementary Education, NCERT. Sumber dari website: http://www.ncert.nic.in/ journal/journal new/ptchap7.htm

Little, A. (1995). Multi-grade Teaching: A Review of Practice and Research, serial No.: 12. Overseas Development Administration, London. Sumber dari website: http://www.ioc.ac.uk/multigrade/ fulltext1littlerevofrandp.htm

Miller, B.A. (1991). "A Review of the Qualitative Research on MultiGrade Instruction". Journal of Research in Rural Education, 7(2), 3-12.

Mulcahy, Dennis. (1992). Multi-Grade and Single Grade: What Is The Difference? Kanada: Faculty of Education. Sumber dari Website: http://www.mun.ca/educ/faculty/mwatch/vol2/mulcahy3.html

Naylor, Charlie. (2000). Split-Grade and Multi-Age Classes: AReview of the Research and a Consideration of the B.C. Context. BCTF research Report, Section XII, 2000-EI-02. January 2000.

Pridmore, Pat. (2004). Bringing the School to the Child: Multigrade schools in Vietnam. Sumber dari website: http://www.ioe.ac.uk/ multigrade/fulltext5pridmorevietnam.htm

Pusat Teknologi Komunikasi dan Informasi Pendidikan-Departemen Pendidikan Nasional. (2002). Laporan Pemantauan dan 
Pembinaan Pemanfaatan Program Audio untuk Pembelajaran Kelas Rangkap di SD. Jakarta: Pusat Teknologi Komunikasi dan Informasi Pendidikan-Departemen Pendidikan Nasional.

Rogers, Paula. (2002). Out of Sight, Out of Mind? Multigrade

Teaching in Nepal. Sumber dari website: http://www.id21.org/ education/E3ts1g1.html

Suzuki, Takako. (2004). Multigrade teaching in Japan, Peru, Sri Lanka, and Vietnam (4 views of multigrade). EID Group, Institute of Education, University of London. Sumber dari website: http:// www.ioe.ac.uk/multigrade/fulltext6JapPerViet.htm

Veenman, S. (1996). "Effects of Multi-Grade and Multi-Age Classes Reconsidered". Review of Educational Research, 66 (3), 323340.

Vu, Son. (2004). Multigrade teaching in Japan, Peru, Sri Lanka, and Vietnam (4 views of multigrade). EID Group, Institute of Education, University of London. Sumber dari website: http://www.ioe.ac.uk/ multigrade/fulltext6JapPerViet.htm

Education's Have-nots. Sumber dari Website: http://www.id21.org/ society/4aDF7.html

Website: http://www.ioe.ac.uk/multigrade/definitions of terms.htm 